Jurnal Health Sains: p-ISSN: 2723-4339 e-ISSN: 2548-1398

Vol. 2, No. 5, Mei 2021

\title{
PERSEPSI, PENGETAHUAN, DAN SIKAP TENTANG OBAT TERHADAP MAHASISWA UNIVERSITAS TADULAKO DI PALU, SULAWESI TENGAH
}

\author{
Rizkika Nabila R. Makka, Amelia Rumi dan Firdawati Amir Parumpu \\ Universitas Tadulako Sulawesi Tengah, Indonesia \\ Email: $\quad$ rizkikanabila19@gmail.com, \\ firdaamirparumpu@gmail.com \\ amelia.rumi@gmail.com \\ dan
}

\begin{tabular}{l}
\hline ARTIKEL INFO \\
\hline Tanggal diterima: 5 Mei 2021 \\
Tanggal revisi: 15 Mei 2021 \\
Tanggal yang disetujui: 25 Mei \\
2021
\end{tabular}

ABSTRACT

Keywords:

perception; knowledge;

attitude; drugs; student

Medicine is a compound that is used for the prevention and cure of disease. Besides having benefits, drugs also have side effects, namely the cause of making mistakes in selfmedication. Irrational use of drugs such as drug abuse is one of the impacts of the low knowledge of students about drugs. This study aims to assess the perceptions, knowledge, and attitudes of Health and Non-Health Students of Tadulako University in the city of Palu regarding medicine. The research was conducted by using descriptive and analytic methods with cross-sectional method using Google Form questionnaire with 345 health students and 395 non-health students. Data were analyzed using univariate and bivariate analysis using the chi-square test. The results showed that the perception of Health Students towards drug safety was categorized as high (88.7\%) while Non-Health Students (72.4\%), Health students having knowledge of medicine was categorized as good (94.2\%) while Non-Health Students had good knowledge. good (86.3\%), and Health Students were positive (64.6\%) but Non-Health Students were negative $(55.7 \%)$. In Health Students there is a relationship between perception and attitude $(0.000<0.05)$, a relationship between perception and knowledge $(0.008<0.05)$ and a relationship between attitude and knowledge (0.019 <0.05). Meanwhile, non-health students have a relationship between perception and attitude $(0.000<0.05)$, but there is no relationship between perception and knowledge $(0.849>0.05)$ and the relationship between attitude and knowledge (0.972>0.05). This shows that low perceptions and knowledge can encourage students to make more fatal mistakes such as drug abuse or irrational drug use.

\begin{abstract}
ABSTRAK
Obat merupakan senyawa yang digunakan untuk pencegahan dan penyembuhan penyakit. Selain memiliki manfaat, obat juga memiliki efek samping yaitu penyebabnya karena melakukan kesalahan dalam pengobatan sendiri. Penggunaan obat yang tidak rasional seperti penyalahgunaan obat merupakan salah satu dampak dari rendahnya pengetahuan mahasiswa tentang obat. Penelitian ini bertujuan untuk
\end{abstract}

$\begin{array}{ll}\text { How to cite: } & \text { Makka, Rizkika Nabila R., et. al (2021) Persepsi, Pengetahuan, dan Sikap Tentang Obat terhadap } \\ & \begin{array}{l}\text { Mahasiswa Universitas Tadulako di Palu, Sulawesi Tengah. Jurnal Health Sains 2(5). } \\ \text { https://doi.org/10.46799/jhs.v2i5.170 }\end{array} \\ \text { E-ISSN: } & 2723-6927 \\ \text { Published by: } & \text { Ridwan Institute }\end{array}$


menilai persepsi, pengetahuan, dan sikap mahasiswa kesehatan dan mahasiswa non kesehatan Universitas Tadulako di Kota Palu tentang obat-obatan. Penelitian dilakukan dengan metode deskriptif dan analitik secara crosssectional menggunakan instrumen kuesioner Google Form dengan jumlah mahasiswa kesehatan 345 orang dan jumlah mahasiswa non kesehatan 395 orang. Data dianalisis menggunakan analisis univariat dan bivariat menggunakan uji chi-square. Hasil yang didapatkan bahwa persepsi mahasiswa kesehatan terhadap keamanan obat dikategorikan tinggi $(88,7 \%)$, sedangkan mahasiswa non kesehatan $(72,4 \%)$, mahasiswa kesehatan memiliki pengetahuan tentang obat dikategorikan baik $(94,2 \%)$ sedangkan mahasiswa non kesehatan memiliki pengetahuan yang baik $(86,3 \%)$, dan mahasiswa kesehatan bersikap positif sebanyak (64,6\%) namun mahasiswa non kesehatan bersikap negatif sebanyak $(55,7 \%)$. Pada mahasiswa kesehatan terdapat hubungan antara persepsi dengan sikap $(0,000<0,05)$, hubungan persepsi dengan pengetahuan $(0,008<0,05)$ dan hubungan sikap dengan pengetahuan $(0,019<0,05)$, sedangkan pada mahasiswa non kesehatan terdapat hubungan antara persepsi dengan sikap $(0,000<0,05)$, namun tidak ada hubungan antara persepsi dengan pengetahuan $(0,849>0,05)$ dan hubungan sikap dengan pengetahuan $(0,972>0,05)$. Hal ini menunjukkan rendahnya persepsi dan pengetahuan dapat

Kata Kunci:

persepsi; pengetahuan; sikap; obat; mahasiswa. mendorong mahasiswa untuk melakukan kesalahan yang lebih fatal seperti penyalahgunaan obat atau penggunaan obat yang tidak rasional.

\section{Pendahuluan}

Obat merupakan suatu zat atau bahanbahan yang berguna dalam menetapkan diagnosa, mencegah, mengurangi, menghilangkan, menyembuhkan penyakit atau gejala penyakit, luka atau kelainan fisik dan rohani pada manusia atau hewan, termasuk mempercantik tubuh atau bagian tubuh manusia (Murtini, 2016). Obat mempunyai dimensi yang sangat luas sehingga masalah yang ditimbulkan akibat penggunan obat akan berdampak langsung pada derajat kesehatan masyarakat. Efek samping obat merupakan respon yang tidak diinginkan dari pengguna obat dan efek samping obat terjadi tidak hanya dari obat itu sendiri, melainkan dapat terjadi karena melakukan kesalahan dalam penggunaan sendiri (Lindell - Osuagwu et al., 2014).
Dari hasil penelitian (Syofyan, 2017), berdasarkan hasil kategorisasi variabel responden menyatakan bahwa persepsi responden tentang keamanan obat dikategorikan tinggi sekitar 95,5\%, sedangkan gambaran pengetahuan responden tentang obat dan penggunaan obat yaitu memiliki pengetahuan yang kurang sekitar 74,8\%. Aspek sikap secara keseluruhan memberikan hasil yang positif dengan jumlah $60,3 \%$. Selain itu, terdapat hubungan antara persepsi dengan sikap $(\mathrm{P}<0,05)$, namun tidak ada hubungan antara pengetahuan dengan tingkat persepsi $(\mathrm{P}>0,05)$ dan antara pengetahuan dengan sikap $(\mathrm{P}>0,05)$. Penting diberikan pendidikan obat kepada siswa karena merupakan kelompok yang berpotensi menggunakan obat untuk swamedikasi. Selain itu, penelitian dari (Fitrianda \& Amna, 2020), 
menunjukan bahwa pengetahuan penggunaan obat pada kalangan mahasiswa perguruan tinggi di Jember termasuk kategori sedang 63,2\% dan sikap penggunaan obat pada kalangan mahasiswa perguruan tinggi di Jember termasuk kategori sedang 64,9\%. Perilaku penggunaan obat pada kalangan mahasiswa perguruan tinggi di Jember menunjukkan bahwa mayoritas mahasiswa tidak pernah meminta obat-obatan resep tanpa membawa resep kepada apoteker 44,7\%, tetapi masih ada mahasiswa yang langsung menghentikan penggunaan obat resep ketika gejala yang dirasakan menghilang.

Pengobatan sendiri banyak dilakukan di berbagai negara pada rentang usia yang beragam (Garofalo et al., 2015). Survey Social Ekonomi Nasional tahun 2019 menunjukkan bahwa penduduk masyarakat yang sakit melakukan pengobatan sendiri sebesar 64,37\% (Apruzzi et al., 2019). Pada saat ini yang sering terjadi adalah pengobatan sendiri yang seharusnya menggunakan resep dokter tetapi tidak menggunakan resep dokter, seperti banyaknya kasus penggunaan antibiotic tanpa resep. Oleh karena itu, pengobatan sendiri harus sesuai dengan batasan penggunaan obat secara rasional.

Penggunaan obat rasional meliputi penggunaan obat sesuai dengan kebutuhan, waktu pemakaian obat dan harga yang terjangkau (Kemenkes, 2011). Pengobatan sendiri dapat menyimpang menjadi pengobatan tidak rasional apabila tidak memperhatikan aturan yang ada. Dalam mengurangi pengobatan sendiri secara tidak rasional maka pengetahuan sangat penting bagi setiap individu karena pengetahuan dapat membantu setiap individu dalam menentukan kebenaran dari sebuah objek (Agiviana \& Djastuti, 2015).

Akibat dari kurangnya pengetahuan tentang obat-obatan para anak-anak, remaja, mahasiswa, maupun yang sudah dewasa sekalipun akan mengambil sikap dengan mengonsumsi obat-obatan terlarang dengan dosis yang lebih tinggi. Sehingga upaya peningkatan pengetahuan tentang obat salah satunya adalah dengan melakukan sosialisasi salah satu program GeMa CerMat (Gerakan Masyarakat Cerdas Menggunakan Obat) yang dirancang oleh Kementerian Kesehatan RI yaitu DAGUSIBU, sosialisasi ini memberikan informasi tentang obat beserta cara menggunakan obat dengan benar (KemenKes, 2016). Hal ini sesuai dengan salah satu penelitian yang menunjukkan adanya peningkatan pengetahuan masyarakat terhadap obat setelah dilakukan sosialisasi (Nuraeni \& Yuliastuti, 2019).

Selain pada pengetahuan yang baik yang harus dimiliki oleh mahasiswa yaitu juga memiliki persepsi yang tinggi dimana persepsi merupakan penilaiaan seriap individu terhadap objek tertentu. Persepsi juga dapat dikatakan sebagai aktivis mengindera, dan penginderaan tersebut tergantung pada stimulus fisik maupun social yang berada di sekitarnya. Menurut (Kurnia et al., 2020) persepsi adalah proses menginterpretasikan sensasi-sensasi yang dirasakan dengan tujuan untuk memberikan makna terhadap lingkungannya. Persepsi dan pengetahuan merupakan faktor penentu sikap, dimana sikap merupakan kecenderungan untuk melakukan sebuah perilaku dengan cara tertentu terhadap sebuah objek (Suharyono \& Ali, 2017).

Sikap adalah reaksi atau respon yang tampak atau tertutup seseorang terhadap objek pada lingkungannya. Sikap terjadi diawali dengan adanya pengetahuan yang dipersepsikan sebagai suatu yang baik (positif) maupun tidak baik (negatif) kemudian diinternalisasikan dalam diri. Jika yang dipersepsikan positif maka seseorang akan cenderung bersikap positif. Sebaliknya, jika yang dipersepsikan negatif maka seseorang akan cenderung bersikap negatif (Septiani et al., 2020). Menurut Newcomb, salah seorang psikolog sosial yang menyatakan bahwa sikap merupakan 
kesediaan dalam bertindak, dan bukan merupakan pelaksanaan motif tertentu. Artinya sikap bersifat tertutup ataupun terbuka dan merupakan predisposisi perilaku seseorang terhadap suatu stimulus.

Berdasarkan studi pendahuluan yang dilakukan peneliti pada 30 mahasiswa di Universitas Tadulako menunjukkan bahwa sebanyak $43,3 \%$ mahasiswa yang mengetahui tentang obat-obatan. Sejumlah 23,3\% memiliki pengetahuan yang baik tentang obat-obatan, sedangkan mahasiswa yang tidak memiliki pengetahuan yang baik tentang obat-obatan sejumlah 76,07\%. Persepsi mahasiswa tentang obat-obatan cukup rendah sekitar $67,08 \%$ terkait dosis dan cara penyimpanan obat yang benar. Selain itu, terdapat sejumlah $86,16 \%$ mahasiswa membeli obat antibiotik tanpa resep dokter maupun konsultasi pada apoteker sehingga hal ini membuktikan bahwa masih banyak mahasiswa belum mempunyai pengetahuan dan persepsi yang benar tentang obat.

Berdasarkan hal tersebut di atas, maka perlu dilakukan penelitian ini untuk mengetahui bagaimana persepsi, pengetahuan dan sikap mahasiswa/i Universitas Tadulako tentang obat dan keamanan obat.

Penelitian ini diharapkan dapat digunakan sebagai data ilmiah untuk bahan pembelajaran dalam tingkat persepsi, pengetahuan dan sikap tentang obat-obatan.

\section{Metode Penelitian}

Penelitian ini termasuk jenis penelitian deksriptif dan analitik dengan menggunakan desain pendekatan cross-sectional. Penelitian deksriptif mendeskripsikan distribusi responden berdasarkan karakterisitiknya, sedangkan penelitian analitik menguji hipotesis dan menaksir besarnya hubungan antar variabel. Metode pengambilan sampel yang digunakan adalah purposive sampling.

Populasi dalam penelitian ini adalah semua mahasiswa yang seang menempuh strata-1 jurusan non kesehatan dan jurusan kesehatan Universitas Tadulako Sulawesi Tengah.

Sampel penelitian ini diambil dari populasi dengan melihat kriteria inklusi dan eksklusi. Dimana kriteria tersebut menentukan dapat atau tidaknya sampel yang digunakan.

\section{Hasil dan Pembahasan}

\section{A. Hasil Penelitian}

\section{Uji Validitas}

Berdasarkan hasil uji validitas didapatkan hasil sebagai berikut:

Tabel 1

Hasil Uji Validitas Persepsi

\begin{tabular}{cccc}
\hline Pertanyaan & rhitung & rtabel & Keterangan \\
\hline P1 & $\mathbf{0 , 1 5 5}$ & 0,361 & Tidak Valid \\
\hline P2 & 0,435 & 0,361 & Valid \\
\hline P3 & $\mathbf{0 , 3 1 9}$ & 0,361 & Tidak Valid \\
\hline P4 & 0,574 & 0,361 & Valid \\
\hline P5 & 0,511 & 0,361 & Valid \\
\hline P6 & 0,502 & 0,361 & Valid \\
\hline P7 & 0,469 & 0,361 & Valid \\
\hline P8 & 0,627 & 0,361 & Valid \\
\hline P9 & 0,369 & 0,361 & Valid \\
\hline P10 & $\mathbf{0 , 0 9 2}$ & 0,361 & Tidak Valid \\
\hline P11 & $\mathbf{0 , 1 2 7}$ & 0,361 & Tidak Valid \\
\hline P12 & 0,404 & 0,361 & Valid \\
\hline P13 & 0,722 & 0,361 & Valid \\
\hline P14 & 0,454 & 0,361 & Valid \\
\hline P15 & 0,598 & 0,361 & Valid \\
\hline
\end{tabular}

Tabel 2

Hasil Uji Validitas Pengetahuan

\begin{tabular}{cccc}
\hline Pertanyaan & $\begin{array}{c}\mathbf{r} \\
\text { hitung }\end{array}$ & $\begin{array}{c}\mathbf{r} \\
\text { tabel }\end{array}$ & Keterangan \\
\hline P1 & $\mathbf{0 , 2 9 9}$ & 0,361 & Tidak Valid \\
\hline P2 & 0,466 & 0,361 & Valid \\
\hline P3 & $\mathbf{0 , 1 6 9}$ & 0,361 & Tidak Valid \\
\hline P4 & $\mathbf{0 , 0 3 1}$ & 0,361 & Tidak Valid \\
\hline P5 & 0,497 & 0,361 & Valid \\
\hline P6 & $\mathbf{0 , 0 7 4}$ & 0,361 & Tidak Valid \\
\hline P7 & $\mathbf{0 , 0 0 1}$ & 0,361 & Tidak Valid \\
\hline P8 & 0,581 & 0,361 & Valid \\
\hline P9 & 0,593 & 0,361 & Valid \\
\hline P10 & $\mathbf{0 , 3 3 5}$ & 0,361 & Tidak Valid \\
\hline & & &
\end{tabular}


Rizkika Nabila R. Makka, Amelia Rumi dan Firdawati Amir Parumpu

\begin{tabular}{cccc}
\hline P11 & 0,466 & 0,361 & Valid \\
\hline P12 & 0,587 & 0,361 & Valid \\
\hline P13 & 0,569 & 0,361 & Valid \\
\hline P14 & $\mathbf{0 , 0 1 1}$ & 0,361 & Tidak Valid \\
\hline P15 & $\mathbf{0 , 2 0 1}$ & 0,361 & Tidak Valid \\
\hline P16 & 0,632 & 0,361 & Valid \\
\hline P17 & 0,661 & 0,361 & Valid \\
\hline P18 & 0,671 & 0,361 & Valid \\
\hline P19 & 0,434 & 0,361 & Valid \\
\hline P20 & $\mathbf{0 , 1 4 1}$ & 0,361 & Tidak Valid \\
\hline
\end{tabular}

Tabel 3

Hasil Uji Validitas Sikap

\begin{tabular}{cccc}
\hline Pertanyaan & $\begin{array}{c}\mathbf{r} \\
\text { hitung }\end{array}$ & $\begin{array}{c}\mathbf{r} \\
\text { tabel }\end{array}$ & Keterangan \\
\hline P1 & 0,766 & 0,361 & Valid \\
\hline P2 & 0,701 & 0,361 & Valid \\
\hline P3 & 0,707 & 0,361 & Valid \\
\hline P4 & $\mathbf{0 , 0 0 1}$ & 0,361 & Tidak Valid \\
\hline P5 & 0,802 & 0,361 & Valid \\
\hline P6 & 0,815 & 0,361 & Valid \\
\hline P7 & 0,788 & 0,361 & Valid \\
\hline P8 & 0,772 & 0,361 & Valid \\
\hline P9 & 0,719 & 0,361 & Valid \\
\hline P10 & 0,414 & 0,361 & Valid \\
\hline P11 & $\mathbf{0 , 3 2 0}$ & 0,361 & Tidak Valid \\
\hline P12 & $\mathbf{0 , 1 0 5}$ & 0,361 & Tidak Valid \\
\hline P13 & $\mathbf{0 , 0 5 5}$ & 0,361 & Tidak Valid \\
\hline P14 & 0,445 & 0,361 & Valid \\
\hline P15 & $\mathbf{0 , 0 0 1}$ & 0,361 & Tidak Valid \\
\hline
\end{tabular}

Menurut (Mahmudah, 2020), validasi adalah instrumen pengukuran dalam mengukur apa yang hendak diukur. Selain itu, uji validasi tidak ditentukan oleh instrumen itu sendiri, ada juga dengan penggunaan alat ukur yang melakukan pengukuran dan subjek yang diukur. Uji validitas diambil berdasarkan data yang didapat dari hasil kuesioner, dengan melalui pengujian korelasi antara skor (nilai) tiap-tiap item (pertanyaan) dengan skor total kuesioner dengan menggunakan software SPSS versi 21 dengan jumlah sampel $(n)=30$ responden sehingga

didapatkan nilai $r$ tabel sebesar 0,361. Instrumen yang dikatakan valid apabila pada saat mengungkap data variabel tidak menyimpang dari keadaan yang sebenarnya atau nilai korelasi (pearson correlation) adalah positif, nilai (probabillitas correlation) (2-tailed)< taraf signifikan $(\alpha)$ 0,05. Dari uji validitas yang telah dilakukan didapatkan hasil pertanyaan yang valid untuk veriabel persepsi berjumlah 11 pertanyaan dari 15 pertanyaan, untuk variabel pengetahuan berjumlah 11 pertanyaan dari 20 pertanyaan, sedangkan untuk variabel sikap berjumlah 10 pertanyaan dari 15 pertanyaan dengan menggunakan 30 responden.

\section{Uji Reliabilitas}

Berdasarkan hasil uji reliabilitas didapatkan hasil sebagai berikut:

Tabel 4

Hasil Uji Reliabilitas Persepsi

\begin{tabular}{cc}
\hline Cronbach's Alpha & N of Items \\
\hline 741 & 11 \\
\hline
\end{tabular}

Tabel 5

Hasil Uji Reliabilitas Pengetahuan

\begin{tabular}{cc}
\hline $\begin{array}{c}\text { Cronbach's } \\
\text { Alpha }\end{array}$ & Norttems \\
\hline 797 & 11 \\
\hline
\end{tabular}

Tabel 6

Hasil Uji Reliabilitas Sikap

\begin{tabular}{cc}
\hline $\begin{array}{c}\text { Cronbach's } \\
\text { Alpha }\end{array}$ & N of Items \\
\hline 878 & 10 \\
\hline
\end{tabular}

Berdasarkan (Yusup, 2018), bahwa reliabilitas merujuk kepada ketepatan pengukuran. Selain itu, reliabiltas hanya menyediakan ketepatan yang memungkinkan validitas. Dengan demikian harus menghitung validitas terlebih dahulu 
sebelum menghitung reliabilitas. Metode yang digunakan untuk mengukur reliabilitas kuesioner adalah dengan metode Cronbach's Alpha. Kuesioner dikatakan reliabel jika Cronbach's Alpha lebih besar dari nilai $r$ table (0,632). Pada hasil yang didapatkan pada variabel persepsi sebesar 0,741, pada variabel pengetahuan sebesar 0,797 , sedangkan pada variabel sikap sebesar 0,878 .

\section{B. Pembahasan}

Berdasarkan pada penelitian yang dilakukan pada mahasiswa kesehatan menunjukkan bahwa dari 345 responden (100\%) lebih banyak yang memiliki persepsi yang tinggi yaitu sebanyak 306 responden $(88,7 \%)$ dan responden yang memiliki persepsi yang rendah yaitu sebanyak 32 responden $(9,2 \%)$. Hasil penelitian pada mahasiswa non kesehatan pada tabel 4.18 menunjukkan bahwa dari 395 responden (100\%) lebih banyak yang memiliki persepsi yang tinggi yaitu sebanyak 286 responden $(72,4 \%)$ dan responden yang memiliki persepsi yang rendah yaitu sebanyak 109 responden $(27,5 \%)$. Sebagian besar responden memiliki persepsi yang cukup tinggi terkait obat-obatan. Terbukti sebagian responden menjawab bahwa tingkat keamanan penggunaan obat berbeda-beda sehingga dibutuhkan informasi mengenai obat yang tepat. Informasi obat dari dokter atau apoteker sangat penting sehingga tidak ada kesalahan yang menyebabkan kesalahgunaan, penyalahgunaan, atau interaksi obat. Namun hal ini tidak menutup kemungkinan bahwa masih ada responden yang memiliki persepsi yang rendah, terbukti masih ada responden yang menjawab bahwa informasi mengenai obat tidak penting sehingga masih ada responden ketika mengkonsumsi obat tanpa konsultasi kepada dokter atau apoteker. Informasi obat perlu dilakukan oleh apoteker atau dokter untuk menunjang penggunaan obat yang rasional sehingga tidak terjadi adanya persepsipersepsi baru yang dapat menentukan tindakan seseorang selanjutnya, sehingga banyak orang yang melakukan tindakan berdasarkan persepsi tetapi berlandaskan pada pengetahuan yang dimilikinya.

Mahasiswa kesehatan memperoleh dari 306 responden $(88,7 \%)$ yang memiliki persepsi yang tinggi, lebih banyak yang memiliki sikap yang positif yaitu sebanyak 216 responden (62,7\%) dibanding responden yang memiliki sikap yang negatif yaitu sebanyak 90 responden (26,0\%). Dari 39 responden (11,3\%) yang memiliki persepsi yang rendah, lebih banyak yang memiliki sikap yang negatif yaitu sebanyak 32 responden $(9,2 \%)$ dibanding yang memiliki sikap yang positif yaitu sebanyak 7 responden $(2,0 \%)$. Hasil penelitian di atas menunjukkan bahwa responden yang memiliki persepsi yang tinggi cenderung sebagian besar memiliki sikap yang positif. Sebaliknya, responden yang memiliki persepsi yang rendah akan berdampak pada sikap yang negatif juga. Hasil analisis menggunakan uji chi-square yang dilakukan bahwa didapatkan hasil $\mathrm{P}=0,000 \quad(\alpha<0,05)$ yang artinya bahwa ada hubungan antara persepsi dengan sikap mahasiswa kesehatan.

Mahasiswa non kesehatan memperoleh dari 286 responden $(72,4 \%)$ yang memiliki persepsi yang tinggi, lebih banyak yang memiliki sikap yang positif yaitu sebanyak 156 responden $(39,4 \%)$ dibanding responden yang memiliki sikap yang negatif yaitu sebanyak 130 responden (33\%). Dari 109 responden $(27,5 \%)$ yang memiliki persepsi yang rendah, lebih banyak yang memiliki sikap yang negatif yaitu sebanyak 90 responden $(22,7 \%)$ dibanding yang memiliki sikap yang positif yaitu sebanyak 19 responden 
(4,8\%). Hasil di atas menunjukkan bahwa responden yang memiliki persepsi yang tinggi sebagian besar akan memiliki sikap yang positif. Begitupun sebaliknya, rendahnya persepsi seseorang maka sikap yang dihasilkan juga akan negatif. Hasil analisis menggunakan uji chi-square yang telah dilakukan bahwa didapatkan hasil $\mathrm{P}=0,000(\alpha<0,05)$ yang artinya bahwa ada hubungan antara persepsi dengan sikap mahasiswa non kesehatan.

Hal ini sejalan dengan penelitian yang dilakukan oleh (Syofyan, 2017) didapatkan hasil uji statistik dengan nilai $\mathrm{P}=0,0005(\alpha<0,05)$ yang berarti terdapat hubungan yang signifikan antara persepsi dengan sikap responden terkait penggunaan obat untuk swamedikasi. Hasil analisis menunjukkan nilai persepsi responden cukup tinggi yaitu $62,9 \%$ mengenai obat-obatan untuk swamedikasi, responden mengemukakan harus adanya kehati-hatian dalam penggunaan obat untuk swamedikasi Selain itu, jika melakukan tindakan dalam melakukan swamedikasi dibarengi dengan pengetahuan yang dimiliki, setidaknya mencari informasi-informasi terkait obat agar tidak terjadi kesalahgunaan dalam menggunakan obat.

Berdasarkan pada penelitian yang dilakukan pada mahasiswa kesehatan menunjukkan bahwa dari 345 responden (100\%) lebih banyak yang memiliki pengetahuan yang baik yaitu sebanyak 325 responden $(94,2 \%)$ dan responden yang memiliki pengetahuan yang kurang yaitu sebanyak 20 responden (5,7\%). Sedangkan hasil penelitian pada mahasiswa non kesehatan menunjukkan bahwa dari 395 responden (100\%) lebih banyak yang memiliki pengetahuan yang baik yaitu sebanyak 341 responden $(86,2 \%)$ dan responden yang memiliki pengetahuan yang kurang yaitu sebanyak 54 responden $(13,6 \%)$. Sebagian besar memiliki pengetahuan yang baik terkait obat karena responden kemungkinan besar sudah memiliki pengetahuan dasar dari keadaan lingkungan sekitar, informasi dari satu individu ke individu lain atau dari informasi melalui internet. Bukti lain juga menyatakan bahwa sebagian besar responden sudah paham dengan cara penyimpanan obat yang benar, dan takaran dosis obat terhadap orang dewasa dan anak-anak itu berbeda-beda. Namun hal ini juga masih ada responden yang belum mengetahui terkait obat, terbukti masih ada responden yang menjawab bahwa semua obat dapat disimpan dilemari pendingin agar lebih tahan lama, dan semua obat termasuk antibiotik dapat dibeli bebas di swalayan. Menurut Direktorat Jenderal Bina Kefarmasian, terkait cara penyimpanan obat dengan benar tergantung bentuk sediaan obat masing-masing. Bila cara penyimpanan obat tidak memenuhi persyaratan dari cara penyimpanan obat yang benar, maka akan terjadi perubahan sifat obat sampai terjadi kerusakan obat (Afqary et al., 2018).

Mahasiswa kesehatan menunjukkan data dari 325 responden (94,2\%) yang memiliki pengetahuan yang baik, lebih banyak yang memiliki persepsi yang tinggi yaitu sebanyak 288 responden $(83,4 \%)$ dibanding responden yang memiliki persepsi yang rendah yaitu sebanyak 37 responden $(10,8 \%)$. Dari 20 responden $(5,7 \%)$ yang memiliki pengetahuan yang kurang, lebih banyak yang memiliki persepsi yang tinggi yaitu sebanyak 18 responden $(5,2 \%)$ dibanding yang memiliki persepsi yang rendah yaitu sebanyak 2 responden $(0,2 \%)$. Hasil di atas menunjukkan bahwa responden lebih banyak memiliki tingkat pengetahuannya yang baik dibandingkan responden yang memiliki tingkat pengetahuan yang kurang baik. Hasil analisis menggunakan uji chisquare yang telah dilakukan bahwa 
didapatkan hasil $\mathrm{P}=0,008(\alpha<0,05)$, yang artinya bahwa ada hubungan antara pengetahuan dengan persepsi mahasiswa kesehatan.

Mahasiswa non kesehatan menunjukkan data dari 341 responden $(86,2 \%)$ yang memiliki pengetahuan yang baik, lebih banyak yang memiliki persepsi yang tinggi yaitu sebanyak 255 responden $(64,5 \%)$ dibanding responden yang memiliki persepsi yang rendah yaitu sebanyak 86 responden $(21,7 \%)$. Dari 54 responden $(5,7 \%)$ yang memiliki pengetahuan yang kurang, lebih banyak yang memiliki persepsi yang tinggi yaitu sebanyak 31 responden $(7,8 \%)$ dibanding yang memiliki persepsi yang rendah yaitu sebanyak 12 responden (5,8\%). Hasil di atas menunjukkan responden sebagian besar memiliki tingkat pengetahuannya yang baik dan cenderung memiliki persepsi yang positif dibandingkan responden yang memiliki tingkat pengetahuan yang kurang baik. Namun, hasil analisis menggunakan uji chi-square yang telah dilakukan bahwa didapatkan hasil $P=0,489 \quad(\alpha>0,05)$, yang artinya bahwa tidak ada hubungan signifikan antara pengetahuan dengan persepsi mahasiswa non kesehatan terkait obat.

Penelitian lain yang mendukung, dilakukan di Kota Pontianak menyatakan tidak terdapat hubungan yang bermakna antara pengetahuan dengan persepsi responden terkait obat, dengan nilai $\mathrm{P}=0,816 \quad(\alpha>0,05)$. Sebagian besar responden memiliki pendidikan terakhir sekolah dasar, sehingga banyak yang tidak memiliki pengetahuan yang memadai terkait obat. Selain itu, persepsi responden termasuk dalam kategori baik dan hanya selisih $1: 2$ dari pengetahuan yang dimiliki responden. Kemudian pada penelitian yang sama dilakukan di Karachi Pakistan oleh (Izham, 2015), bahwa responden memiliki persepsi yang baik terhadap obat walaupun memiliki pengetahuan yang kurang mengenai obat, hal ini disebabkan oleh beberapa faktor eksternal yaitu kontras, pengulangan, perubahan intensitas, serta sesuatu yang menjadi perhatian orang banyak.

Berbeda dengan hasil penelitian yang dilakukan oleh (Mohtar \& Lawford, 2016) dengan 96 responden berusia $15-54$ tahun, menyatakan bahwa terdapat hubungan yang signifikan antara tingkat pengetahuan terhadap persepsi masyarakat tentang penggunaan obat. Pengetahuan seseorang dapat dilihat dari tingkat pendidikan yang dapat mempengaruhi seseorang akan pola hidup terutama bagi kesehatan, sehingga makin baik pendidikan seseorang maka makin mudah untuk menerima informasi dan semakin banyak pula pengetahuan yang dimiliki.

Banyak faktor yang dapat mempengaruhi persepsi seseorang terhadap obat yaitu sikap, kebutuhan, situasi lingkungan sekitar, pengalaman dari masa lalu, serta penilaian-penilaian (Sanitario, 2016). Hasil analisis dari peneliti dalam penelitian ini faktor yang mungkin mempengaruhi diantaranya pengalaman dari masa lalu, pengaruh dari teman sebaya, dan pendidikan formal yang ditempuh mahasiswa non kesehatan.

\section{Kesimpulan}

Berdasarkan hasil penelitian yang diperoleh, maka didapatkan kesimpulan pertama persepsi mahasiswa kesehatan terkait obat dikategorikan tinggi yaitu sebanyak $(88,7 \%)$ sedangkan persepsi mahasiswa non kesehatan terkait obat dikategorikan tinggi yaitu sebanyak (72,4\%). Kedua pengetahuan mahasiswa kesehatan terkait obat dikategorikan baik yaitu sebanyak $(94,2 \%)$ sedangkan pengetahuan mahasiswa non kesehatan yang dikategorikan baik yaitu sebanyak (86,3\%). Ketiga sikap mahasiswa kesehatan terkait obat dikategorikan positif 
yaitu sebanyak $(64,6 \%)$ sedangkan sikap mahasiswa non kesehatan memiliki sikap negatif yaitu sebanyak (55,7\%). Keempat ada hubungan persepsi dengan sikap mahasiswa kesehatan dengan nilai $(0,000<0,05)$ dan ada hubungan persepsi dengan sikap mahasiswa non kesehatan dengan nilai $(0,000<0,05)$. Kelima ada hubugan persepsi dengan pengetahuan mahasiswa kesehatan dengan nilai $(0,008<0,05)$ namun tidak ada hubungan persepsi dengan pengetahuan mahasiswa non kesehatan dengan nilai $(0,849>0,05)$. Keenam $a$ da hubungan sikap dengan pengetahuan mahasiswa kesehatan $(0,019<0,05)$ namun tidak ada hubungan sikap dengan pengetahuan mahasiswa non kesehatan dengan nilai $(0,972>0,05)$.

\section{BIBLIOGRAFI}

Afqary, M., Wiyanti, D., \& Firliah, I. (2018). Evaluasi Waktu Tunggu Pelayanan Resep Racikan Poli Spesialis Anak Pasien Bpjs Di Rumah Sakit Medika Dramaga Bogor. Jurnal Farmamedika (Pharmamedika Journal), 3(2), 68-72. Google Scholar

Agiviana, A. P., \& Djastuti, I. (2015). Analisis Pengaruh Persepsi, Sikap, Pengetahuan Dan Tempat Kerja Terhadap Perilaku Keselamatan Karyawan. Diponegoro Journal of Management, 21-29. Google Scholar

Apruzzi, F., Lawrie, C., Lin, L., SchäferNameki, S., \& Wang, Y.-N. (2019). Fibers Add Flavor. Part I. Classification Of 5d Scfts, Flavor Symmetries And Bps States. Journal Of High Energy Physics, 2019(11), 1-107. Google Scholar

Fitrianda, A., \& Amna, Z. (2020). The Difference Of Fear of Failure On Undergraduate Students Of Engineering Faculty Based On Gender. Computer, 3(1), 4. Google Scholar

Garofalo, L., Di Giuseppe, G., \& Angelillo, I.
F. (2015). Self-Medication Practices Among Parents In Italy. Biomed Research International, 2015. Google Scholar

Izham, T. N. S. I. T. (2015). Factors Influencing The Project Success From The Contractors' Perspective. Universiti Teknologi Malaysia. Google Scholar

Kemenkes, R. I. (2016). Buku Kesehatan Ibu Dan Anak. In Kementrian Kesehat Ri Dan Jica Jakarta. Google Scholar

Kemenkes, R. I. (2011). Kementerian Kesehatan Ri. Buletin Jendela, Data Dan Informasi Kesehatan: Epidemiologi Malaria Di Indonesia. Jakarta: Bhakti Husada. Google Scholar

Kurnia, I., Zhang, G., Han, X., \& Yu, J. (2020). Zwitterionic-Anionic Surfactant Mixture For Chemical Enhanced Oil Recovery Without Alkali. Fuel, 259, 116236. Google Scholar

Lindell - Osuagwu, L., Hakkarainen, M., Sepponen, K., Vainio, K., Naaranlahti, T., \& Kokki, H. (2014). Prescribing For Off - Label Use And Unauthorized Medicines In Three Paediatric Wards In F Inland, The Status Before And After The E Uropean U Nion P Aediatric R Egulation. Journal of Clinical Pharmacy And Therapeutics, 39(2), 144-153. Google Scholar

Mahmudah, N. (2020). Sistem Bagi Hasil 212 Mart Di Samarinda Dalam Perspektif Figh Muamalah. Iain Samarinda. Google Scholar

Mohtar, R. H., \& Lawford, R. (2016). Present And Future Of The Water-Energy-Food Nexus And The Role Of The Community Of Practice. Journal of Environmental Studies And Sciences, 6(1), 192-199. Google Scholar

Murtini, W. (2016). Implementasi Model "Gepprak" Dalam Pembelajaran Kewirausahaan Untuk Meningkatkan 
Persepsi, Pengetahuan, dan Sikap Tentang Obat terhadap Mahasiswa Universitas Tadulako di Palu, Sulawesi Tengah

Minat Berwirausaha Di Sekolah Menengah Kejuruan. Jurnal Pendidikan Vokasi, 6(3), 335-345. Google Scholar

Nuraeni, Y., \& Yuliastuti, A. (2019). Analisis Efektifitas Layanan Terpadu Satu Atap Dalam Rangka Melindungi Pekerja Migran Indonesia. Seminastika, 24-34. Google Scholar

Sanitario, H. (2016). Torres Domínguez, Juan Alejandro; Guarneros Soto, Noé El Impacto De Los Determinantes Sociales De La Salud En Una Comunidad Marginada Horizonte Sanitario, Vol. 15, Núm. 1, Enero-Abril, 2016, Pp. 25-36 Universidad Juárez Autónoma De Tabasco Villahermosa, México. Horizonte Sanitario, 15(1), 25-36. Google Scholar

Septiani, N. L. W., Kaneti, Y. V., Guo, Y., Yuliarto, B., Jiang, X., Ide, Y., Nugraha, N., Dipojono, H. K., Yu, A., \& Sugahara, Y. (2020). Holey Assembly Of Two-Dimensional Iron-Doped
Nickel - Cobalt Layered Double Hydroxide Nanosheets For Energy Conversion Application. Chemsuschem, 13(6), 1645-1655. Google Scholar

Suharyono, S., \& Ali, H. (2017). Pengaruh Motivasi, Kedisiplinan Dan Gaya Kepemimpinan Terhadap Prestasi Kerja Pegawai Pada Dinas Sosial Tenaga Kerja Dan Transmigrasi Kabupaten Batang Hari. Jurnal Ilmiah Universitas Batanghari Jambi, 15(2), 78-86. Google Scholar

Syofyan, A. (2017). Analisis Kinerja Bank Syariah Dengan Metode Indeks Maqasid Syariah Di Indonesia. Al-Masraf: Jurnal Lembaga Keuangan Dan Perbankan, 2(2), 145-158. Google Scholar

Yusup, F. (2018). Uji Validitas Dan Reliabilitas Instrumen Penelitian Kuantitatif. Tarbiyah: Jurnal Ilmiah Kependidikan, 7(1). Google Scholar

\section{Copyright holder:}

Rizkika Nabila R. Makka, Amelia Rumi dan Firdawati Amir Parumpu (2021)

First publication right:

Jurnal Health Sains

This article is licensed under: 